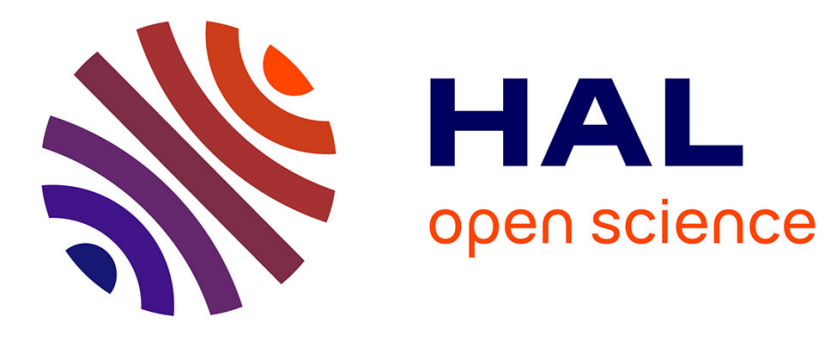

\title{
Plank-Shaped Column-Forming Mesogens with Substituents on One Side Only
}

Edivandro Girotto, Marli Ferreira, Parantap Sarkar, Ahmed Bentaleb, Elisabeth A. Hillard, Hugo Gallardo, Fabien Durola, Harald Bock

\section{To cite this version:}

Edivandro Girotto, Marli Ferreira, Parantap Sarkar, Ahmed Bentaleb, Elisabeth A. Hillard, et al.. Plank-Shaped Column-Forming Mesogens with Substituents on One Side Only. Chemistry - A European Journal, 2015, 21, pp. 7603-7610. 10.1002/chem.201500048 . hal-01153866

\section{HAL Id: hal-01153866 https://hal.science/hal-01153866}

Submitted on 2 Feb 2021

HAL is a multi-disciplinary open access archive for the deposit and dissemination of scientific research documents, whether they are published or not. The documents may come from teaching and research institutions in France or abroad, or from public or private research centers.
L'archive ouverte pluridisciplinaire HAL, est destinée au dépôt et à la diffusion de documents scientifiques de niveau recherche, publiés ou non, émanant des établissements d'enseignement et de recherche français ou étrangers, des laboratoires publics ou privés. 


\title{
Plank-shaped column-forming mesogens with substituents on one side only
}

\author{
Edivandro Girotto, ${ }^{[\mathrm{a}]}$ Marli Ferreira, ${ }^{[\mathrm{ab},[\mathrm{b}]}$ Parantap Sarkar, ${ }^{[\mathrm{c}]}$ Ahmed Bentaleb, ${ }^{[\mathrm{a}]}$ Elizabeth A. Hillard, ${ }^{[\mathrm{a}]}$ \\ Hugo Gallardo, ${ }^{[b]}$ Fabien Durola, ${ }^{[a]}$ and Harald Bock ${ }^{*[a]}$ \\ [a] Centre National de la Recherche Scientifique, Centre de Recherche Paul Pascal, 115 avenue Schweitzer, 33600 Pessac, France. \\ [b] Departamento de Química, Universidade Federal de Santa Catarina, 88040-900 Florianópolis, SC, Brazil. \\ [c] Université de Bordeaux, Centre de Recherche Paul Pascal, 115 avenue Schweitzer, 33600 Pessac, France. \\ Fax: +33-556845600; Tel: +33-556845673; E-mail: bock@crpp-bordeaux.cnrs.fr
}

\begin{abstract}
Prolonged glyoxylation of pyrenyl-1-glyoxylic acid ethyl ester leads to a mixture of isomers with the polar pyrenylene-1,8-diglyoxylic acid as the main product, whereas the centrosymmetric 1,6-isomer is obtained in good yield from the corresponding dibromopyrene. Perkin condensations followed by Pd-catalyzed cyclizations lead to isomeric dinaphtopyrene-tetracarboxdiimides that self-assemble into columnar liquid crystals of hexagonal and rectangular symmetry, of which the rectangular mesophases have unusually elongated unit cells. The cisoid diimides with both alkylimide substituents on the same side of the oblong arene system show a much greater tendency to self-assemble into fluid stacks of disks than their centrosymmetric isomers. With racemically branched alkyl substituents, uniform vertical surface alignment of the columns in the high-temperature hexagonal mesophase is resilient to cycling through the lower-temperature rectangular and crystalline phases.
\end{abstract}

\section{Introduction}

Columnar liquid crystals, in which roughly disk-shaped molecules stack to form a bidimensional crystalline lattice of columns with liquid-like disorder in the third dimension, are most often formed by polycyclic arenes that bear a circular or near-circular surrounding of flexible polar alkyl-terminated substituents such as alkoxy RO-, alkanoyloxy $\mathrm{RCO}_{2}$ - or alkoxycarbonyl ROCO-. ${ }^{[1][2]}$ Due to their chemical robustness, cyclic dicarboximide substituents $\mathrm{RN}(\mathrm{CO}-)_{2}$ that give self-assembling materials of good to moderate electron acceptor strength are of particular interest in organic electronics. Columnar liquid crystalline materials with more than two such imide moieties are rare because their synthesis necessitates the challenging introduction of at least three pairs of vicinal carboxylic substituents. ${ }^{[3]}$ Mesogenic materials with two such imide moieties are rare because two substituents are often not enough to induce liquid crystalline behavior, but the use of a-branched ("swallowtailed") alkylimide substituents RR' $\mathrm{CHN}(\mathrm{CO}-)_{2}$ yields in some cases columnar mesophases, especially if the two branches $\mathrm{R}$ and $\mathrm{R}^{\prime}$ are not identical, yielding stereoisomeric mixtures with increased stabilization of the mesophase against crystallization. ${ }^{[4][5]}$

Having recently found that swallow-tailed dinaphtho[1,2-b;1,2-k]perylene-tetracarboxdiimides 1, derived from centrosymmetric perylenylene-3,9-diglyoxylic acid 2 via a double Perkin condensation with 2-bromophenylacetic acid 3 (Fig. 1), form enantiotropic columnar mesophases, ${ }^{[5]}$ we aimed at preparing analogous dinaphtho[2,1a;2,1-h]pyrene-diimides 4 via two-fold Friedel-Crafts alkylation of pyrene with ethyl chloroglyoxylate $\mathrm{ClCOCO}_{2} \mathrm{Et}$. 


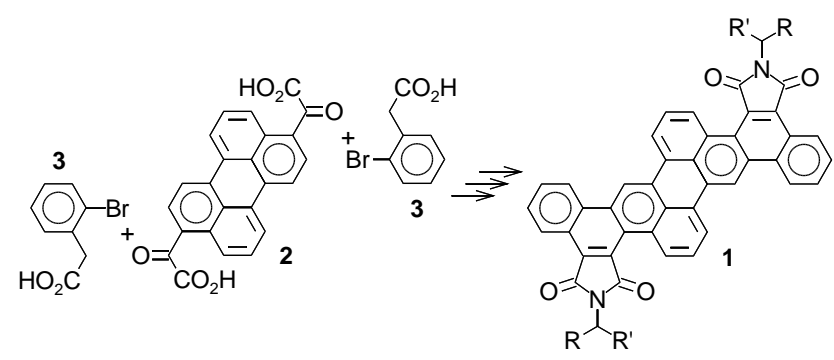

Figure 1. Synthesis of columnar liquid crystalline dinaphthoperylene-dicarboximides $\mathbf{1}$ from perylenylene-diglyoxylic acid 2 with bromophenylacetic acid $\mathbf{3}$ by Perkin condensation followed by $\mathrm{Pd}$-catalyzed dehydrobromination and final imidification with $\mathrm{RR}^{\prime} \mathrm{CHNH}_{2}$. $^{[5]}$

\section{Results and Discussion}

In contrast to the swift diacetylation of pyrene with acetyl chloride in the presence of $\mathrm{AlCl}_{3},{ }^{[6]}$ the entry of a second glyoxylic substituent into ethyl pyrenyl-1-glyoxylate 5 (Fig. 2) necessitates a prolonged reaction time and leads to a partially hydrolyzed product. Whereas the diacetylation is over after $2 \mathrm{~h}$ at room temperature, the second acylation of $\mathbf{5}$ is still incomplete after $24 \mathrm{~h}$. Longer reaction times do not lead to better yields due to significant decomposition in the presence of excess $\mathrm{AlCl}_{3}$, whereas the use of only equimolar amounts of $\mathrm{AlCl}_{3}$ with respect to the sum of $\mathbf{5}$ and $\mathrm{ClCOCO}_{2}$ Et gives insignificant conversion. Whereas the initially targeted 1,6-isomer $\mathbf{7}$ is only formed in minor amounts and could not be isolated pure, the 1,8-isomer 8 as well as the 1,3-isomer 6 are obtained in $29 \%$ and $13 \%$ isolated yield with respect to converted 5 (Prior to isomer separation, the 6:7:8 isomer ratio is $4: 1: 7$ as determined by ${ }^{1} \mathrm{H}$-NMR). An alternative access to arylene-diglyoxylates is the reaction of arylenedianions, generated by BuLi from the corresponding dibromoarene, with diethyl oxalate. ${ }^{[7]}$ We thus could obtain pure 7 in 80\% yield from commercially available 1,6-dibromopyrene 9 (Fig. 2). Saponification of the isomeric diglyoxylic esters $\mathbf{7}$ and $\mathbf{8}$ yielded the diacids $\mathbf{1 0}$ and $\mathbf{1 1}$, whose Perkin condensations with $\mathbf{3}$ gave the isomeric tetrapropyl bismaleates 12 and 13 after in situ esterification. Subsequent double cyclodehydrobromination led to the dinaphthopyrene-tetracarboxylates $14 a$ and $15 \mathbf{a}$. We chose propyl as an alkyl group to obtain crystalline bismaleates 12 and $\mathbf{1 3}$ (longer alkyl groups lead to liquid homologues) whilst still ensuring good solubility of the cyclization products $14 a$ and $15 a$. The latter then were transformed into the swallow-tail diimides 4a-e and 16a-e. 


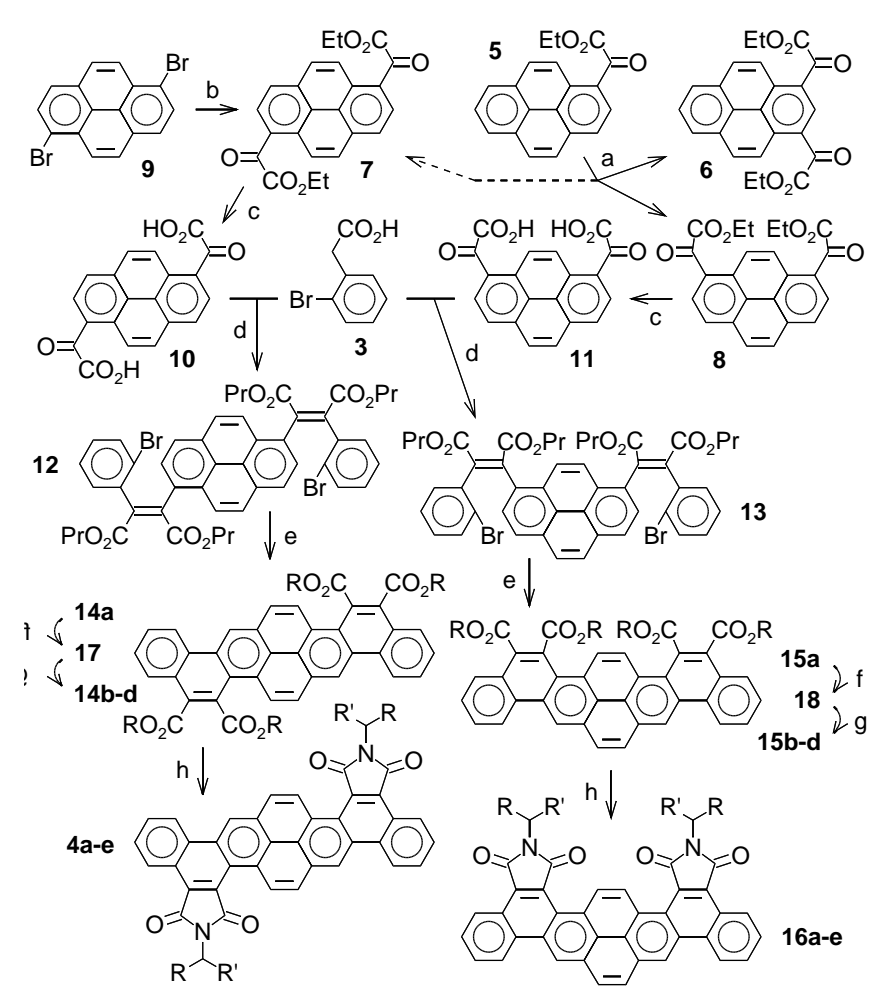

Figure 2. Synthesis of isomeric dinaphthopyrene-tetracarboxylic esters 14, 15 and imides 4, 16. 14a, 15a: $R=P r ; 14 b, 15 b: R=E t, 14 c, 15 c: R=n$-octyl; 14d, 15d $\mathrm{R}=\mathrm{CH}_{2} \mathrm{CH}_{2} \mathrm{CHMeEt}$; 4a, 16a: $\mathrm{R}=\mathrm{R}^{\prime}=n$-pentyl; 4b, 16b: $\mathrm{R}=\mathrm{R}^{\prime}=n$-undecyl; 4c, 16c: $\mathrm{R}=\mathrm{Pr}, \mathrm{R}^{\prime}=n$-heptyl; 4d, 16d: $\mathrm{R}=n$-hexyl, $\mathrm{R}^{\prime}=n$-nonyl; 4e, 16e: $\mathrm{R}=\mathrm{Bu}, \mathrm{R}^{\prime}=n$ undecyl; 17, 18: R=H. (a) $\mathrm{ClCOCO}_{2} \mathrm{Et}, \mathrm{AlCl}_{3}, \mathrm{DCM}, 25^{\circ} \mathrm{C}, 24 \mathrm{~h}$, then $\mathrm{EtOH}, \mathrm{SOCl}_{2}, 3 \mathrm{~h}$, then $\mathrm{DCM}$, conc. aq. $\mathrm{HCl}, 16 \mathrm{~h}, 29 \%(8) / 13 \%(6) ;(\mathrm{b}) \mathrm{THF}, \mathrm{BuLi},-94^{\circ} \mathrm{C}, 1 \mathrm{~h}$

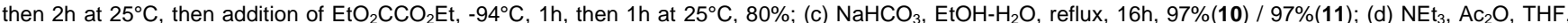
reflux, 16h, then $\mathrm{PrOH}, \mathrm{PrBr}$, DBU, reflux, 2h, 67\%(12)/55\%(13); (e) $\mathrm{Pd}(\mathrm{OAc})_{2}, \mathrm{PCy}_{3}, \mathrm{~K}_{2} \mathrm{CO}_{3}, \mathrm{DMA}, 110^{\circ} \mathrm{C}, 19 \mathrm{~h}, 90 \%(\mathbf{1 4 a}) / 83 \%(\mathbf{1 5 a}) ;(f) \mathrm{KOH}, \mathrm{HOCH} \mathrm{CH}_{2} \mathrm{OH}$, reflux, 16h, then $\mathrm{HCl}$; (g) $\mathrm{RBr}, \mathrm{ROH}$, DBU, THF, reflux, 16h, 40-60\% (2 steps); (h) $\mathrm{RR}^{\prime} \mathrm{CHNH}_{2}$, imidazole, o- $\mathrm{C}_{6} \mathrm{H}_{4} \mathrm{Cl}_{2}, \mathrm{reflux}, 16 \mathrm{~h}, 40-90 \%$.

To evaluate the mesogenic potential of tetraesters with different alkyl groups, the propyl esters 14a and 15a were also transformed via the acids 17 and 18 into their homologues $14 \mathrm{~b}-\mathbf{d}$ and $\mathbf{1 5 b}-\mathbf{d}$ with shorter (ethyl), longer (octyl) and racemically branched (3-methylpentyl) alkyl groups, but none of the tetraesters shows a mesophase.

To probe the liquid crystalline behavior of the diimides 4 and 16, we prepared homologues with symmetric and asymmetric (racemic) swallow-tails by reacting the esters $14 a$ and $15 b$ with 6 -aminoundecane (4a, 16a), 12aminotricosane (4b, 16b), 4-aminoundecane (4c, 16c), 7-aminohexadecane (4d, 16d) and 5-aminohexadecane $(4 e, 16 e)$.

Whereas the short symmetric alkyl groups in $4 a$ and 16 a proved too short to obtain accessible melting points (Mp. $>320^{\circ} \mathrm{C}$ ), the long symmetric alkyl groups in $\mathbf{4 b}$ and $\mathbf{1 6 b}$ lead to low phase transition temperatures. Surprisingly, transoid $\mathbf{4 b}$ shows no mesophase, and after melting at $77^{\circ} \mathrm{C}$, remains an isotropic liquid at room temperature, whereas cisoid 16b shows an enantiotropic columnar mesophase between the melting point at 60 ${ }^{\circ} \mathrm{C}$ and the clearing point at $114^{\circ} \mathrm{C}$, that slowly gives way to crystals upon standing at room temperature. Between glass plates, the mesophase grows upon cooling from the isotropic liquid in pseudohomeotropic fingered domains with residual birefringence (Fig. 3), indicating that the mesophase is not of the usual hexagonal symmetry. This is confirmed by small angle X-ray scattering (SAXS) at elevated temperature (Fig. 4), which testifies to a rectangular columnar mesophase with a surprisingly elongated unit cell. Whilst the aspect ratio of the two-column unit rectangle in rectangular columnar mesophases usually deviates only little from the hexagonal case of aspect ratio $a / b=\sqrt{ } 3=1.73,{ }^{[1][8]}$ the unit rectangle in the mesophase of $16 \mathbf{b}$ has an aspect ratio of $a / b=$ 2.24 (at $110^{\circ} \mathrm{C}$ ) to 2.27 (at $40^{\circ} \mathrm{C}$ ), indicating a pronounced ellipticity of the column cross-sections. The absence of liquid crystalline behavior in $\mathbf{4 b}$ and the formation of a rectangular mesophase by $\mathbf{1 6 b}$ contrasts with the behavior 
of the swallow-tailed dinaphtho[1,2-b;1,2-k]perylene-diimides 1 , whose mesophases are of hexagonal symmetry. ${ }^{[5]}$

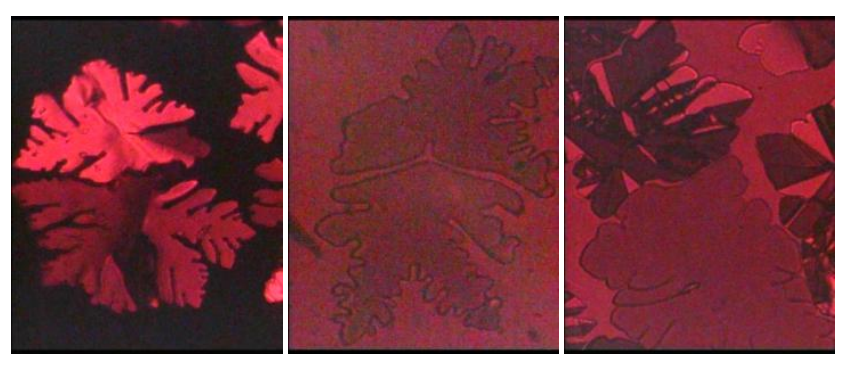

Figure 3. Mesophase domains growing from the isotropic liquid between glass plates on cooling through the liquid to mesophase transition of $16 \mathrm{~b}$ (left, pseudohomeotropic with residual birefringence), 16c (center, homeotropic) and $\mathbf{4 d}$ (right, homeotropic that transits to birefringent during growth: only the bottom domain is still homeotropic). Polarizing optical microscopy (POM) with crossed (left) or slightly uncrossed (center, right) polarizers, $0.24 \mathrm{~mm} \times 0.30 \mathrm{~mm}$.

The short asymmetric alkyl chains in $\mathbf{4 c}$ and $\mathbf{1 6 c}$ lead to an appreciable decrease in the transition temperatures compared to the symmetric isomers $4 \mathbf{a}$ and $16 \mathbf{a}$. Transoid $4 \mathbf{c}$ melts at $283^{\circ} \mathrm{C}$ and shows no mesophase, whereas cisoid $16 \mathrm{c}$, which melts at $310^{\circ} \mathrm{C}$, shows a monotropic hexagonal columnar mesophase below $309^{\circ} \mathrm{C}$, identified by its growth in non-birefringent homeotropic domains (Fig. 3). Lengthening the asymmetric alkyl groups leads to liquid crystalline behavior not only in the cisoid isomer $\mathbf{1 6 d}$, but also in the transoid $\mathbf{4 d}$. $\mathbf{4 d}$ melts at $198^{\circ} \mathrm{C}$ to a slightly enantiotropic rectangular mesophase, and clears to the isotropic liquid at $200^{\circ} \mathrm{C}$. On cooling, non-birefringent homeotropic domains, characteristic of a hexagonal mesophase, start to grow from the isotropic liquid, but abruptly transit to the birefringent texture of the rectangular mesophase before the domain growth is completed (Fig. 3). Cisoid $16 \mathrm{~d}$, which melts at $166^{\circ} \mathrm{C}$ and clears at $248^{\circ} \mathrm{C}$, has the same two mesophases over much larger temperature domains, with a rectangular-to-hexagonal transition at $225^{\circ} \mathrm{C}$ as revealed by differential scanning calorimetry (DSC, Fig. 5). The rectangular mesophases of $\mathbf{4 d}$ and $\mathbf{1 6 d}$ (Fig. 4) both have unit rectangles of large aspect ratios, albeit smaller than in 16b (4d: 2.05 at 190ㅜ, 16d: 2.06 at $210^{\circ} \mathrm{C}$ to 2.10 at $150^{\circ} \mathrm{C}$ ). 


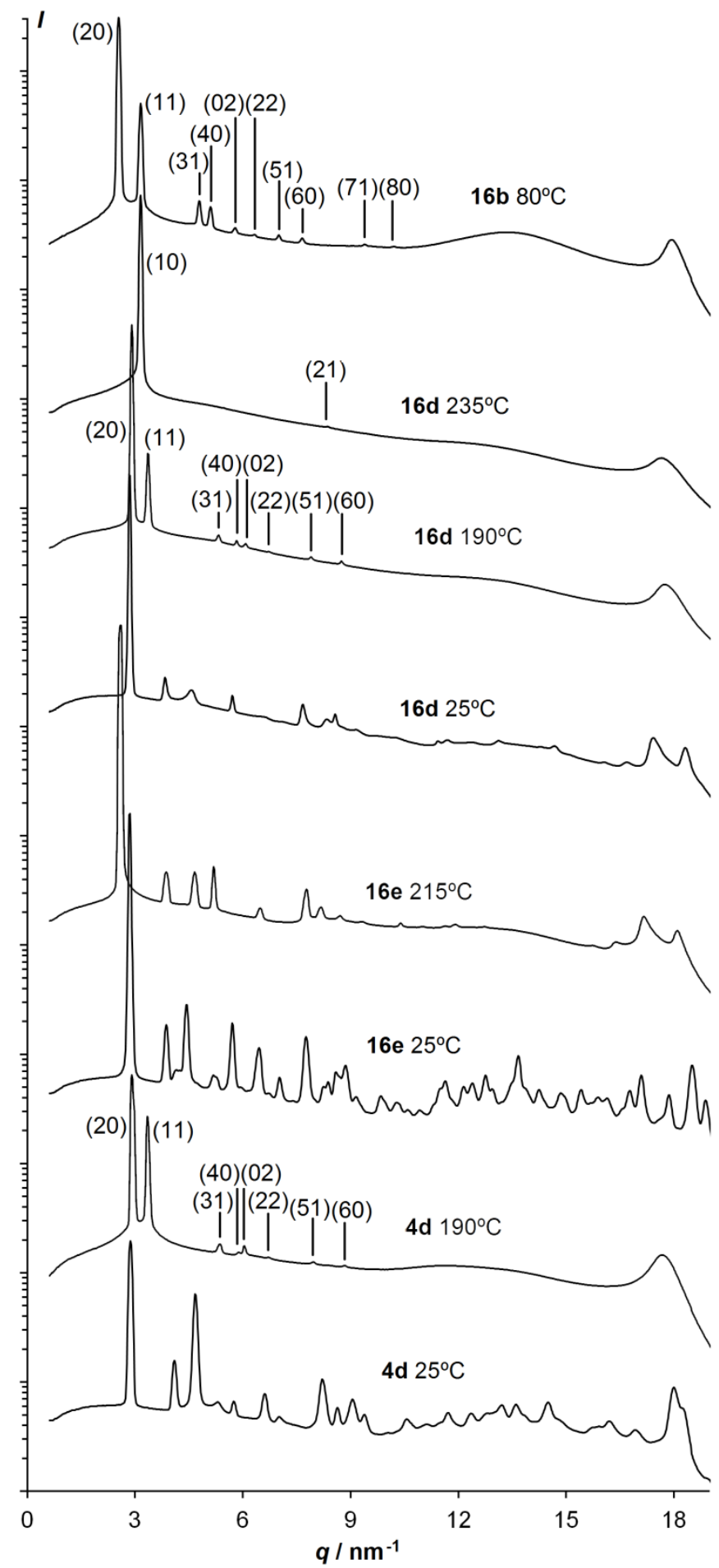

Figure 4. SAXS spectra of $\mathbf{1 6 b}, \mathbf{1 6 d}, \mathbf{1 6 e}$ and $\mathbf{4 d}$ after cooling from the isotropic liquid (logarithmic intensity scaling). The Miller indices indicated in brackets correspond to a column lattice of rectangular symmetry, except for $\mathbf{1 6 d}$ at $235^{\circ} \mathrm{C}$, where they correspond to a column lattice of hexagonal symmetry. Non-indexed spectra correspond to crystalline phases. 


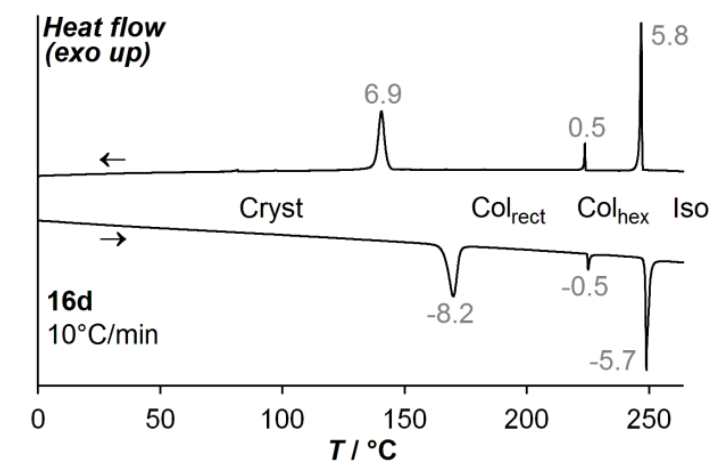

Figure 5. DSC traces of $\mathbf{1 6 d}$ (top: first cooling, bottom: second heating), showing the transition sequence crystal - rectangular mesophase - hexagonal mesophase - isotropic liquid. First and second heating scans show no notable difference. Measured transition enthalpies in gray $(\mathrm{J} / \mathrm{g})$.

With two columns per rectangular unit cell or three columns per hexagonal unit cell and assuming one molecule per disk, the unit cell sizes and disk-to-disk spacings obtained by SAXS yield densities slightly above $1 \mathrm{~g} / \mathrm{cm}^{3}$ in all cases ${ }^{[9]}$ which indicates that, despite the elongated molecular shape and the presence of flexible substituents on only one side in the case of $\mathbf{1 6 b}$ and $\mathbf{1 6 d}$, the molecules do not pair up to form supramolecular disks, but are functional disks in themselves. Even though geometrical considerations evidently suggest that neighboring disks within a column should have a tendency to orient themselves with their alkyl moieties on alternating sides of the column, any such alternation is not regular enough to leave any signature on the SAXS spectra of neither the hexagonal nor the rectangular mesophase. This contrasts with the many known cases where two or more molecules are found to form supramolecular disks which in turn form columns. These cases include polycatenar mesogens, i.e. rod-like polycyclic moieties with more than two flexible terminal substituents, ${ }^{[10]}$ half-disk-shaped metal-organic species, ${ }^{[11]}$ bent-core mesogens ${ }^{[12]}$ and asymmetrically substituted phthalocyanines. ${ }^{[13]}$

The large deviation of the aspect ratio $a / b$ of the rectangular phases, which is greater than 2 in all cases (Fig. $6)$, from the aspect ratio of a hexagonal column lattice $(a / b=1.73)$, also suggests that the lattice is rectangular centered, i.e. of $\mathrm{C} 2 \mathrm{~m}$ (2D centered) symmetry, with all elliptical column cross sections oriented in parallel. ${ }^{[1]}$ Whereas the deviations from the hexagonal aspect ratio of $a / b=1.73$ are in general small in rectangular columnar mesophases with non-parallel elliptical column cross-sections (i.e. of $\mathrm{P} 2{ }_{1} / a$ or $\mathrm{P} 2 / a$ symmetry) ${ }^{[14]}$ large deviations have been reported for mesophases of $\mathrm{C} 2 \mathrm{~m}$ symmetry, albeit the deviations for hexakis(alkoxybenzoyloxy)-triphenylenes and -truxenes go into the opposite direction, with $a / b<1.5^{[14]}$. The $\mathrm{C} 2 \mathrm{~m}$ symmetry is also supported by the fact that all eight $(\mathbf{4 d}, \mathbf{1 6 d})$ or ten $(\mathbf{1 6 b})$ observable lattice reflections obey the rule $h+k=2$ (see ESI), a constraint that is not valid for the other two known symmetries of rectangular columnar mesophases ( $\mathrm{P}_{1} / a$ and $\left.\mathrm{P} 2 / a\right) \cdot{ }^{[1]} \mathrm{C} 2 m$ symmetry implies that not only the elliptical cross-sections are parallel, but also that both columns of the unit cell tilt to the same side (Fig 6).

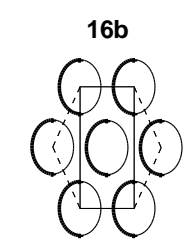

rectangular $\mathrm{C} 2 \mathrm{~m}$

$30 \%$ elongation $\mathrm{a} / \mathrm{b}=$ c. 2.25
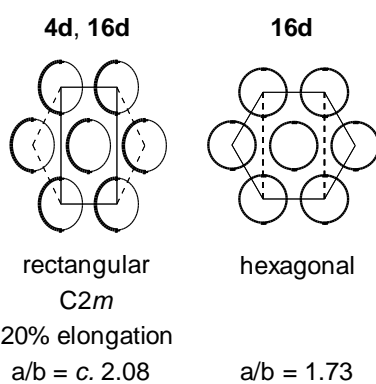

Figure 6. Deviation (as obtained from SAXS) of the column cross sections from circular and of the column lattices form hexagonality in the rectangular mesophases of $\mathbf{1 6 b}$ (left, $30 \%$ elongation) and $\mathbf{1 6 d}$ and $\mathbf{4 d}$ (middle, $20 \%$ elongation) with respect to the hexagonal mesophase (right) such as present in $\mathbf{1 6} \mathbf{d}$ at high temperature. The rectangular mesophases are represented with uniform tilt directions corresponding to C2m symmetry. (See ESI for full SAXS data.) 
On cooling to room temperature, $\mathbf{4} \mathbf{d}$ forms a crystalline state with many well-expressed SAXS peaks, whereas 16d gives a crystalline phase with considerably weaker and less numerous secondary peaks, which may hint to some form of plastic crystal with residual molecular mobility (Fig. 4). When cooling down samples of $\mathbf{1 6 d}$ between glass plates from the temperatures of the isotropic liquid, a homogeneous homeotropic texture of the hexagonal mesophase is formed, which transits to the rectangular phase under formation of a dense hexagonal pattern of defects (Fig. 7). Upon further cooling, the crystalline phase forms in very small and opaque domains. Surprisingly, no memory of domain boundaries is observed on reheating, as first the hexagonal pattern of the rectangular phase and then the featureless largely defect-free homeotropic texture of the hexagonal phase reform. This suggests that the upright surface orientation of the columns in the hexagonal phase is retained both

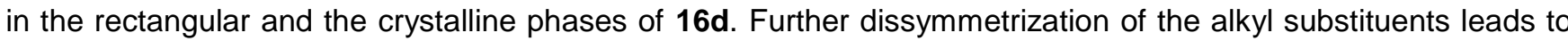
the absence of any mesophase in $4 \mathbf{e}$ and $16 \mathbf{e}$, which melt at $214^{\circ} \mathrm{C}$ and $231^{\circ} \mathrm{C}$, but $16 \mathrm{e}$ shows a reversible transition between two crystalline phases, of which the room temperature state shows many well-expressed SAXS peaks, whereas the higher temperature crystalline phase that forms from the former at $195^{\circ} \mathrm{C}$ gives a SAXS spectrum that is strikingly similar to the room temperature crystalline phase of $\mathbf{1 6 d}$ (Fig. 4).

The phase transitions of $\mathbf{1 6 b - e}$ and $\mathbf{4 d}$ are summarized in Table 1. See Fig. 5 and ESI for the corresponding DSC scans.

Table 1: Phase transition temperatures $\left({ }^{\circ} \mathrm{C}\right)$ of $\mathbf{1 6 b}-\mathbf{e}$ and $\mathbf{4 d}$, with transition enthalpies in brackets $(\mathrm{J} / \mathrm{g})$, as determined by DSC, SAXS and POM.

\begin{tabular}{|c|c|}
\hline $\mathbf{4 d}$ & Cryst $-198[7.6]-$ Col $_{\text {rect }}-200[4.8]-$ Iso \\
\hline 16b & Cryst $-60[24]-$ Col $_{\text {rect }}-114[1.8]-$ Iso \\
\hline 16c & Cryst $-310[16]-\left(\right.$ Col $\left._{\text {hex }}-309[7.9]-\right)$ Iso \\
\hline 16d & Cryst $^{\star}-166[8.2]-$ Col $_{\text {rect }}-225[0.5]-$ Col $_{\text {hex }}-248[5.7]-$ Iso \\
\hline 16e & Cryst $-195[1.6]-$ Cryst $^{*}-231[12]-$ Iso \\
\hline
\end{tabular}

The improved liquid-crystallinity of the cisoid homologues $\mathbf{1 6}$ compared to their transoid counterparts $\mathbf{4}$ is in line with other cases where a reduction of symmetry leads to improved mesogenic behavior such as reduced transition temperatures or plastic crystalline order, eg. in hexasubstituted triphenylenes. ${ }^{[15]}$ Low symmetry has even been found to lead to columnar liquid crystals in the absence of any flexible alkyl periphery. ${ }^{[16]}$

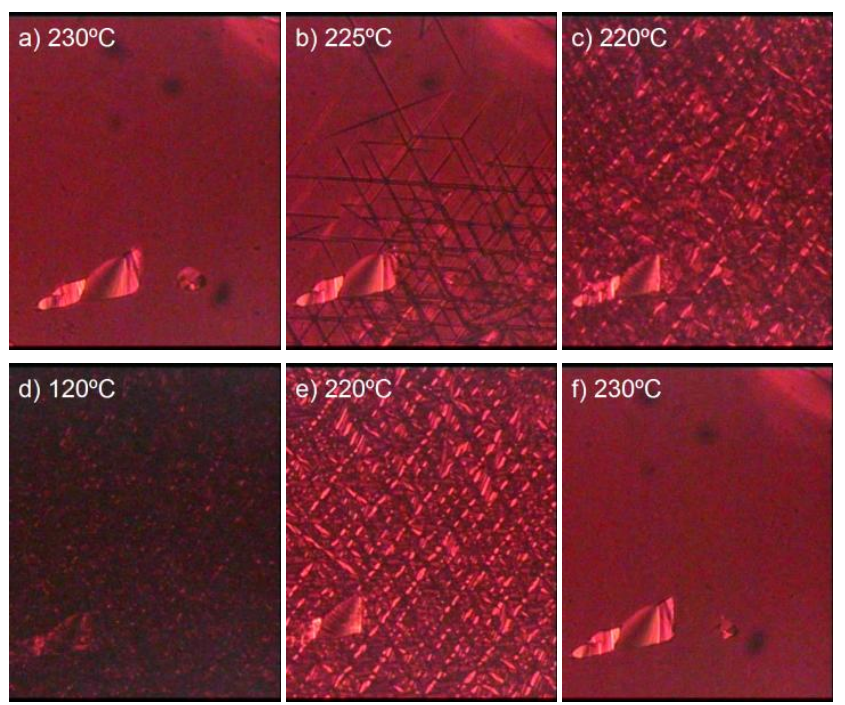

Figure 7. Sequence of textures at different temperatures of an initially homeotropic sample of 16d between glass plates. Two small domains in birefringent planar orientation are visible at the bottom. Chronological order from a) to f). a) Initial homeotropic texture of the hexagonal mesophase obtained by cooling from the isotropic liquid; b) appearance of a hexagonal defect pattern at the transition to the rectangular mesophase; c) resulting texture of the rectangular mesophase; $d$ ) 
opaque texture of the crystalline phase; e) recovery of the texture of the rectangular mesophase on reheating; f) full recovery of a uniform homeotropic texture on further reheating. POM with slightly uncrossed polarizers, $0.24 \mathrm{~mm} \times 0.30 \mathrm{~mm}$.

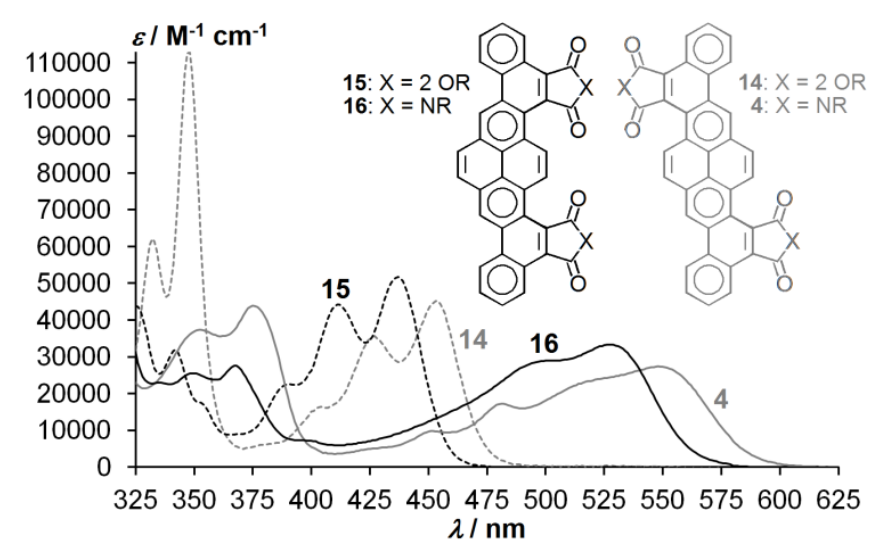

Figure 8: Absorption spectra of tetraesters $14 a$ and $15 a$ (dashed) and diimides $4 \mathbf{d}$ and $16 \mathrm{~d}$ (continuous), $20 \mu \mathrm{M}(\mathbf{1 4 a}$ : $10 \mu \mathrm{M})$ in $\mathrm{CHCl}_{3}$. Gray: $\mathbf{1 4 a}$ and $\mathbf{4 d}$, black: $15 \mathrm{a}$ and $16 \mathrm{~d}$.

The absorption spectra in dilute solution of the cisoid esters 15 and imides 16 show a significant hypsochromic shift compared to the transoid esters 14 and imides 4, with absorption onsets at 470nm, 580nm, $485 \mathrm{~nm}$ and $600 \mathrm{~nm}$, respectively (Fig. 8), corresponding to optical band gaps of $2.64 \mathrm{eV}, 2.14 \mathrm{eV}, 2.56 \mathrm{eV}$ and $2.07 \mathrm{eV}$. The color difference between cisoid and transoid isomers is particularly visible in the case of the imides: Dilute solutions of $\mathbf{1 6}$ in chloroform are deep orange, whereas those of $\mathbf{4}$ are purplish red.

This difference in band gaps between the cisoid and transoid diimides is confirmed by cyclic voltammetry of $\mathbf{4 d}$ and $\mathbf{1 6 d}$ in DCM solution. For both compounds, two quasi-reversible, partially superimposed reduction waves are discerned, with average $E_{1 / 2}$ values of -1.48 and $-1.63 \mathrm{~V}$ vs. $\mathrm{Fc} / \mathrm{Fc}^{+}$for $4 \mathrm{~d}$ and -1.52 and $-1.65 \mathrm{~V}$ for $16 \mathrm{~d}$ (Fig. SI1, SI3) The anodic behavior of the two imides is qualitatively identical. The first oxidation is reversible with $E_{1 / 2}=+0.82 \mathrm{~V}$ for $\mathbf{4 d}$ and $+0.85 \mathrm{~V}$ for $\mathbf{1 6} \mathbf{d}$. For both compounds, a second, irreversible peak is observed at more positive potential. The irreversibility of this peak is likely due to a chemical transformation following the second oxidation, due to the appearance of a new reversible peak at $E_{1 / 2}=+0.37 \mathrm{~V}(\mathbf{4 d})$ and $+0.45 \mathrm{~V}(\mathbf{1 6 d})$ upon a second sweep. This peak is only observed when the window is enlarged to include the second oxidation process (Fig. SI2, SI4). The reduction and oxidation potentials vs. $\mathrm{Fc} / \mathrm{Fc}^{+}$of $-1.48 \mathrm{~V}$ and $+0.82 \mathrm{~V}(\mathbf{4 d})$ and of $-1.52 \mathrm{~V}$ and $+0.85 \mathrm{~V}(\mathbf{1 6 d})$ correspond to $E_{\text {LUmo }}$ and $E_{\text {Hомо }}$ values of $-3.32 \mathrm{eV}$ and $-5.62 \mathrm{eV}(\mathbf{4 d})$ and to $-3.29 \mathrm{eV}$ and -5.6 $\mathrm{eV}(\mathbf{1 6 d})$. The resulting electrochemical band gaps of $2.30 \mathrm{eV}(\mathbf{4 d})$ and $2.37 \mathrm{eV}(\mathbf{1 6 d})$ are $0.23 \mathrm{eV}$ larger than the optical values, with the differences attributable to the exciton binding energies.

\section{Conclusions}

In summary, the stepwise two-fold acylation of pyrene with ethyl chloroglyoxylate leads to a mixture of three isomers made up mainly of 1,8-isomer 8 and 1,3-isomer 7, with the centrosymmetric 1,6-isomer 6 formed only in a minor amount. The latter is more conveniently obtained by treatment of 1,6-dibromopyrene 9 with butyllithium and diethyl oxalate. Both 6 and 8 are converted in three steps into the isomeric dinaphthopyrenetetracarboxdiimides 4 and 16, who exhibit distinct colors and electrochemical band gaps and differ strikingly in their tendencies to self-assemble into columnar liquid crystals. The roughly board-shaped mesogenic diimides 16 with their flexible alkyl substituents both on the same side form enantiotropic columnar phases and thus are able to function as semi-flexible molecular disks despite their far-from-circular and non-centrosymmetric form. Besides 
hexagonal mesophases, they exhibit rectangular columnar mesophases whose unit cells are strongly elongated with respect to the hexagonal case. The polar one-sided diimides $\mathbf{1 6}$ are much more mesogenic than the corresponding centrosymmetric diimides 4 with substituents at opposite positions of the aromatic center. This can be tentatively explained by the more flexible columnar stacking that is possible between molecules of $\mathbf{1 6}$, where lateral displacement is limited only on one side by the imide groups on neighboring molecules, whereas in $\mathbf{4}$, aromatic $\pi-\pi$ stacking has to accommodate space-demanding substituents on opposing extremities of the central dinaphthopyrene unit. Despite the considerable differences between the aspect ratios of the column lattices in the two mesophases, the uniform surface alignment of surface-oriented domains of homologue $16 \mathrm{~d}$ with racemically a-branched alkyl chains is retained through cooling-reheating cycles from the high-temperature hexagonal mesophase via the rectangular mesophase into the low-temperature crystalline state and back to the hexagonal mesophase.

\section{Experimental Section}

NMR spectra were recorded on a JEOL ECS-40 spectrometer, UV/visible spectra with a Unicam UV 4 spectrometer. Differential scanning calorimetry (DSC) was performed on a Perkin-Elmer DSC7 apparatus, and polarizing optical microscopy on a Olympus BH-2 microscope. Mass spectra were performed on a QStar Elite mass spectrometer (Applied Biosystems) in positive mode. Powder X-ray diffraction data were collected on a Rigaku Nanoviewer (XRF microsource generator, MicroMax 007HF), with a 1200-W rotating anode coupled to a confocal MaxFlux ${ }^{\circledR}$ Osmic mirror (Applied Rigaku Technologies, Austin, USA) and a MAR345 image plate detector (MARResearch, Norderstedt, Germany); samples were put in glass capillaries which were exposed to the X-Ray beam in a high temperature oven; the detector was placed at a distance of $309 \mathrm{~mm}$ providing access to $2 \theta$ angles in the $0.5^{\circ}$ to $29^{\circ}$ range. Cyclic voltammograms (CVs) were obtained in a three electrode cell, utilizing an Autolab PGStat20 potentiostat, driven by GPES software (General Purpose Electrochemical System, Version 4.4, EcoChemie B.V., Utrecht, the Netherlands), a platinum wire counter electrode, a $1.6 \mathrm{~mm}$ platinum disc working electrode, and a non-aqueous reference electrode comprised of a silver wire in a $0.01 \mathrm{M}$ solution of $\mathrm{AgNO}_{3}$ and $0.1 \mathrm{M}$ tetrabutylammonium perchlorate in acetonitrile; the analytes (approximately $1 \mathrm{mM}$ ) were dissolved dichloromethane supplemented with $0.1 \mathrm{M}$ tetrabutylammonium hexafluorophosphate and degassed with argon prior to measurement; CVs were obtained at $50,100,500,1000$ and $2000 \mathrm{mV} / \mathrm{s} ; E_{1 / 2}$ values for reversible or quasireversible processes were determined using the relation $E_{1 / 2}=\left(E_{p}{ }^{a}+E_{p}{ }^{c}\right) / 2$ at $500 \mathrm{mV} / \mathrm{s}$; All values are referenced vs. $\mathrm{Fc} / \mathrm{Fc}^{+}$, which was added as an internal standard at the end of the measurement sequence.

\section{Diethyl pyrenylene-1,6-diglyoxylate 7}

To a stirred suspension of 1,6-dibromopyrene $(8.0 \mathrm{~g}, 360.0 \mathrm{~g} / \mathrm{mol}, 22.2 \mathrm{mmol})$ in dry THF $(250 \mathrm{~mL})$ under argon, a $2.5 \mathrm{M}$ solution of butyllithium in hexane $(35 \mathrm{~mL}, 87.5 \mathrm{mmol})$ ) is added dropwise at $-94^{\circ} \mathrm{C}$ (acetone-liquid nitrogen cooling bath), and the mixture is stirred for $1 \mathrm{~h}$ at $-94^{\circ} \mathrm{C}$. The cooling bath is removed and stirring is continued for $2 \mathrm{~h}$ at room temperature. The mixture is cooled again to $-94^{\circ} \mathrm{C}$, and diethyl oxalate $(30 \mathrm{~mL}, 1.077 \mathrm{~g} / \mathrm{mL}, 32.3 \mathrm{~g}$, $146.1 \mathrm{~g} / \mathrm{mol}, 220 \mathrm{mmol}$ ) is quickly added, and the mixture is stirred for $1 \mathrm{~h}$. Then the cooling bath is removed and stirring is continued for $1 \mathrm{~h}$ at room temperature. The mixture is poured into $2 \mathrm{M}$ aqueous hydrochloric acid $(200 \mathrm{~mL})$ and extracted with $\mathrm{DCM}(3 \times 100 \mathrm{~mL})$, and the combined organic phases are dried over sodium sulfate and concentrated. The product is purified by recrystallization in ethanol. Yield: $7.2 \mathrm{~g}(402.4 \mathrm{~g} / \mathrm{mol}, 17.9 \mathrm{mmol}, 80 \%)$ of orange solid.

${ }^{1} \mathrm{H}-\mathrm{NMR}\left(\mathrm{CDCl}_{3}, 400 \mathrm{MHz}\right): \delta=9.34(\mathrm{~d}, 9 \mathrm{~Hz}, 2 \mathrm{H}), 8.40(\mathrm{~d}, 8 \mathrm{~Hz}, 2 \mathrm{H}), 8.30(\mathrm{~d}, 8 \mathrm{~Hz}, 2 \mathrm{H}), 8.26(\mathrm{~d}, 9 \mathrm{~Hz}, 2 \mathrm{H}), 4.55(\mathrm{q}, 7 \mathrm{~Hz}, 4 \mathrm{H}), 1.49(\mathrm{t}, 7 \mathrm{~Hz}, 6 \mathrm{H}) \mathrm{ppm}$.

${ }^{13} \mathrm{C}-\mathrm{NMR}\left(\mathrm{CDCl}_{3}, 100 \mathrm{MHz}\right): \delta=189.0,164.7,134.2,131.0,130.6,130.3,127.4,126.3,125.8,123.8,62.9,14.4 \mathrm{ppm}$.

FD-HRMS (m/z): $\mathrm{M}^{+}$Calcd for $\mathrm{C}_{24} \mathrm{H}_{18} \mathrm{O}_{6} 402.1103$; found 402.1094 .

Mp.: $162-165^{\circ} \mathrm{C}$.

\section{Diethyl pyrenylene-1,8- and -1,3-diglyoxylates 8 and 6}

A solution of ethyl pyrenyl-1-glyoxylate ${ }^{[17]} \mathbf{5}(18.14 \mathrm{~g}, 302.3 \mathrm{~g} / \mathrm{mol}, 60 \mathrm{mmol})$ and ethyl chloroglyoxylate $(20.5 \mathrm{~g}, 136.5 \mathrm{~g} / \mathrm{mol}, 150 \mathrm{mmol})$ in DCM $(500 \mathrm{~mL})$ is added to a vigorously stirred slurry of anhydrous aluminium chloride $(40 \mathrm{~g}, 133.3 \mathrm{~g} / \mathrm{mol}, 300 \mathrm{mmol}$ in DCM $(500 \mathrm{~mL})$ in a $1 \mathrm{~L}$ flask. The blue mixture is stirred at room temperature under exclusion of moisture for $24 \mathrm{~h}$ and then poured with stirring into $2 \mathrm{M}$ aqueous hydrochloric acid (1L), whereupon a precipitate forms. Acetone $(0.5 \mathrm{~L})$ is added to the biphasic mixture to redissolve the precipitate, the phases are separated, and the organic phase is dried over magnesium sulfate and concentrated to dryness. To reesterify the so obtained partially hydrolyzed product mixture, the residue is dissolved in absolute ethanol $(1 \mathrm{~L})$, thionyl chloride $(100 \mathrm{~mL}, 119.0 \mathrm{~g} / \mathrm{mol}, 1.638 \mathrm{~g} / \mathrm{mL}, 1.38 \mathrm{~mol})$ is added cautiously through a reflux condenser, and the mixture is refluxed for $3 \mathrm{~h}$ under exclusion of moisture and then concentrated to dryness. To reconvert diethyl ketal side products into the desired ketoesters, the residue is dissolved in DCM $(700 \mathrm{~mL})$, concentrated hydrochloric acid is added $(100 \mathrm{~mL})$ and the biphasic mixture is stirred for $16 \mathrm{~h}$ at room temperature. The phases are separated, the organic phase is dried over magnesium sulfate and concentrated to dryness, and the residue is chromatographed on silica, first with a 1:1 mixture of petrol ether and DCM to elute starting material, the with DCM whereby the less polar 1,3-isomer 6 elutes prior to the more polar 1,8-isomer $\mathbf{8}$. The recovered starting material $\mathbf{5}$ is recrystallized from ethanol (yield: $3.55 \mathrm{~g}, 11.7 \mathrm{mmol}, 20 \%$ ), 8 is recrystallized from ethy acetate, 6 from a 1:1 mixture of ethyl acetate and ethanol. Yield: $5.63 \mathrm{~g}(14.0 \mathrm{mmol}, 402.4 \mathrm{~g} / \mathrm{mol}, 29 \%$ with respect to nonrecovered starting material) of 8 and $2.53 \mathrm{~g}(6.3 \mathrm{mmol}, 402.4 \mathrm{~g} / \mathrm{mol}, 13 \%)$ of 6 , both as orange crystals.

1,8-isomer 8:

${ }^{1} \mathrm{H}-\mathrm{NMR}\left(\mathrm{CDCl}_{3}, 400 \mathrm{MHz}\right): \delta=9.37(\mathrm{~s}, 2 \mathrm{H}), 8.42(\mathrm{~d}, 8 \mathrm{~Hz}, 2 \mathrm{H}), 8.29(\mathrm{~d}, 8 \mathrm{~Hz}, 2 \mathrm{H}), 8.21(\mathrm{~s}, 2 \mathrm{H}), 4.55(\mathrm{~d}, 7 \mathrm{~Hz}, 4 \mathrm{H}), 1.49(\mathrm{~d}, 7 \mathrm{~Hz}, 6 \mathrm{H}) \mathrm{ppm}$.

${ }^{13} \mathrm{C}-\mathrm{NMR}\left(\mathrm{CDCl}_{3}, 100 \mathrm{MHz}\right): \delta=188.9,164.7,135.3,130.9,130.51,130.46,127.7,126.4,126.1,124.3,62.9,14.4 \mathrm{ppm}$.

FD-HRMS (m/z): $\mathrm{M}^{+}$Calcd for $\mathrm{C}_{24} \mathrm{H}_{18} \mathrm{O}_{6} 402.1103$; found 402.1111

Mp.: 196-199ㅇ.

1,3-isomer 6 : 
${ }^{1} \mathrm{H}-\mathrm{NMR}\left(\mathrm{CDCl}_{3}, 400 \mathrm{MHz}\right): \delta=9.32(\mathrm{~d}, 9 \mathrm{~Hz}, 2 \mathrm{H}), 8.83(\mathrm{~s}, 1 \mathrm{H}), 8.51(\mathrm{~d}, 9 \mathrm{~Hz}, 2 \mathrm{H}), 8.42(\mathrm{~d}, 8 \mathrm{~Hz}, 2 \mathrm{H}), 8.18(\mathrm{t}, 8 \mathrm{~Hz}, 1 \mathrm{H}), 4.54(\mathrm{q}, 7 \mathrm{~Hz}, 4 \mathrm{H}), 1.49(\mathrm{t}, 7 \mathrm{~Hz}$, 6H) ppm.

${ }^{13} \mathrm{C}-\mathrm{NMR}\left(\mathrm{CDCl}_{3}, 100 \mathrm{MHz}\right): \delta=188.0,164.4,135.3,135.2,134.5,130.0,129.5,127.6,125.2,124.1,123.4,123.0,63.0,14.4 \mathrm{ppm}$.

FD-HRMS (m/z): $\mathrm{M}^{+}$Calcd for $\mathrm{C}_{24} \mathrm{H}_{18} \mathrm{O}_{6} 402.1103$; found 402.1122 .

Mp.: $169-171^{\circ} \mathrm{C}$.

\section{Pyrenylene-1,6-diglyoxylic acid 10}

To a stirred refluxing solution of diethyl ester $7(3.0 \mathrm{~g}, 402.4 \mathrm{~g} / \mathrm{mol}, 7.5 \mathrm{mmol})$ in ethanol $(80 \mathrm{~mL})$, a solution of sodium bicarbonate $(17 \mathrm{~g}, 84.0 \mathrm{~g} / \mathrm{mol}$, $0.2 \mathrm{~mol})$ in water $(200 \mathrm{~mL})$ is added and the mixture is stirred at reflux for $16 \mathrm{~h}$. The homogenous solution is cooled to room temperature and poured cautiously into $2 \mathrm{M}$ aqueous hydrochloric acid $(200 \mathrm{~mL})$, the precipitate is filtered off and washed with water on the glass frit. The crude product is dissolved in acetone, acetone-insoluble salts are filtered off and discarded, and the acetone is evaporated. The solid obtained is used without further purification. Yield: $2.5 \mathrm{~g}(346.3 \mathrm{~g} / \mathrm{mol}, 7.3 \mathrm{mmol}, 97 \%)$.

${ }^{1} \mathrm{H}-\mathrm{NMR}\left(\mathrm{DMSO}-\mathrm{d}_{6}, 400 \mathrm{MHz}\right): \delta=9.22(\mathrm{~d}, 9 \mathrm{~Hz}, 2 \mathrm{H}), 8.57(\mathrm{~d}, 8 \mathrm{~Hz}, 2 \mathrm{H}), 8.53(\mathrm{~d}, 8 \mathrm{~Hz}, 2 \mathrm{H}), 8.50(\mathrm{~d}, 9 \mathrm{~Hz}, 2 \mathrm{H}) \mathrm{ppm}$ (no discrete acid proton detected).

${ }^{13} \mathrm{C}-\mathrm{NMR}\left(\mathrm{DMSO}-\mathrm{d}_{6}, 100 \mathrm{MHz}\right): \delta=191.2,166.3,133.6,130.53,130.46,130.0,126.6,126.3,123.3 \mathrm{ppm}$.

\section{Pyrenylene-1,8-diglyoxylic acid 11}

Diglyoxylic acid 11 is obtained from diethyl ester $8(9.0 \mathrm{~g}, 402.4 \mathrm{~g} / \mathrm{mol}, 22.5 \mathrm{mmol})$ following the preceding procedure with tripled quantities and is used without further purification. Yield: $7.5 \mathrm{~g}(346.3 \mathrm{~g} / \mathrm{mol}, 21.9 \mathrm{mmol}, 97 \%)$.

${ }^{1} \mathrm{H}-\mathrm{NMR}\left(\mathrm{DMSO}-\mathrm{d}_{6}, 400 \mathrm{MHz}\right): \delta=9.20(\mathrm{~d}, 9 \mathrm{~Hz}, 2 \mathrm{H}), 8.54(\mathrm{~d}, 8 \mathrm{~Hz}, 2 \mathrm{H}), 8.50(\mathrm{~d}, 8 \mathrm{~Hz}, 2 \mathrm{H}), 8.48(\mathrm{~d}, 9 \mathrm{~Hz}, 2 \mathrm{H}) \mathrm{ppm}$ (no discrete acid proton detected).

${ }^{13} \mathrm{C}-\mathrm{NMR}\left(\mathrm{DMSO}-\mathrm{d}_{6}, 100 \mathrm{MHz}\right): \delta=191.1,166.2,134.6,130.9,130.4,129.0,126.8,126.7,125.8,123.3 \mathrm{ppm}$.

\section{Tetrapropyl 1,6-pyrenylenebis((2-bromophenyl)maleate) 12}

Diglyoyxlic acid $10(2.5 \mathrm{~g}, 346.3 \mathrm{~g} / \mathrm{mol}, 7.3 \mathrm{mmol}), 2$-bromophenylacetic acid $(3.8 \mathrm{~g}, 214.0 \mathrm{~g} / \mathrm{mol}, 17.8 \mathrm{mmol})$, triethylamine $(4.3 \mathrm{~g}, 101.2 \mathrm{~g} / \mathrm{mol}, 42.7 \mathrm{mmol})$ and acetic anhydride $(5.9 \mathrm{~g}, 102.1 \mathrm{~g} / \mathrm{mol}, 57.7 \mathrm{mmol})$ are stirred at reflux in THF $(60 \mathrm{~mL})$, under exclusion of moisture for $16 \mathrm{~h}$. Then a solution of 1,8 diazabicyclo[5.4.0]undec-7-ene (DBU, $11.2 \mathrm{~g}, 152.2 \mathrm{~g} / \mathrm{mol}, 73.5 \mathrm{mmol}), 1$-bromopropane $(17.5 \mathrm{~g}, 122.0 \mathrm{~g} / \mathrm{mol}, 143.1 \mathrm{mmol})$ and 1 -propanol $(12.7 \mathrm{~g}$, $60.1 \mathrm{~g} / \mathrm{mol}, 210.8 \mathrm{mmol})$ in THF $(60 \mathrm{~mL})$ is added and stirring at reflux is continued under exclusion of moisture for $2 \mathrm{~h}$. The reaction mixture is cooled to room temperature and poured into $2 \mathrm{M}$ aqueous hydrochloric acid. The mixture is extracted with chloroform (250mL), the organic phase is dried over sodium sulfate and the solvent is evaporated. Methanol $(150 \mathrm{~mL})$ is added and the yellow precipitate is purified by column chromatography in DCM on silica and recrystallization from methanol $(150 \mathrm{~mL})$. Yield: $4.4 \mathrm{~g}(908.7 \mathrm{~g} / \mathrm{mol}, 4.8 \mathrm{mmol}, 67 \%)$ of pale yellow solid.

${ }^{1} \mathrm{H}-\mathrm{NMR}\left(\mathrm{CDCl}_{3}, 400 \mathrm{MHz}\right): \delta=8.36(\mathrm{~d}, 9 \mathrm{~Hz}, 2 \mathrm{H}), 8.25-7.72$ (broad, $\left.6 \mathrm{H}\right)$ 7.55-7.20 (broad, 2H) 7.10-6.55 (broad, $\left.6 \mathrm{H}\right), 4.21$ (t, $\left.7 \mathrm{~Hz}, 4 \mathrm{H}\right), 4.30-4.05$ (broad, $4 \mathrm{H}), 1.67$ (sext, $7 \mathrm{~Hz}, 4 \mathrm{H}), 1.70-1.52$ (broad, $4 \mathrm{H}$ ), 0.88 (t, $7 \mathrm{~Hz}, 6 \mathrm{H}), 0.90-0.70$ (broad, $6 \mathrm{H}$ ) ppm.

The strong signal broadening due to slow rotations, evident from the ${ }^{1} \mathrm{H}-\mathrm{NMR}$ spectrum, did not allow the recording of a meaningful ${ }^{13} \mathrm{C}$-NMR spectrum. FD-HRMS (m/z): $\mathrm{M}^{+}$Calcd for $\mathrm{C}_{48} \mathrm{H}_{44} \mathrm{Br}_{2} \mathrm{O}_{8}$ 906.1403; found 906.1400 .

Mp.: $190-192^{\circ} \mathrm{C}$.

\section{Tetrapropyl 1,8-pyrenylenebis((2-bromophenyl)maleate) 13}

Diglyoxylic acid $11(7.2 \mathrm{~g}, 346.3 \mathrm{~g} / \mathrm{mol}, 20.8 \mathrm{mmol}), 2$-bromophenylacetic acid $(11.0 \mathrm{~g}, 214.0 \mathrm{~g} / \mathrm{mol}, 51.4 \mathrm{mmol})$, triethylamine $(12.5 \mathrm{~g}, 101.2 \mathrm{~g} / \mathrm{mol}$, $123.5 \mathrm{mmol})$ and acetic anhydride $(17.0 \mathrm{~g}, 102.1 \mathrm{~g} / \mathrm{mol}, 166.5 \mathrm{mmol})$ are stirred at reflux in THF $(180 \mathrm{~mL})$ under exclusion the moisture for $16 \mathrm{~h}$. Than a solution of DBU (31.3g, $152.2 \mathrm{~g} / \mathrm{mol}, 212.2 \mathrm{mmol}), 1$-bromopropane $(50.4 \mathrm{~g}, 122.0 \mathrm{~g} / \mathrm{mol}, 413.1 \mathrm{mmol})$ and 1 -propanol $(36.6 \mathrm{~g}, 60.1 \mathrm{~g} / \mathrm{mol}, 609.0 \mathrm{mmol})$ in THF $(150 \mathrm{~mL})$ is added and stirring at reflux is continued under exclusion of moisture for $2 \mathrm{~h}$. The reaction mixture is cooled to room temperature and poured into $2 \mathrm{M}$ aqueous hydrochloric acid. The mixture is extracted with chloroform $(500 \mathrm{~mL})$, the organic phase is dried over sodium sulfate and the solvent is evaporated. The residue is dissolved in methanol $(500 \mathrm{~mL})$, and the yellow product is precipitated by adding water $(200 \mathrm{~mL})$ and purified by column chromatography on silica in DCM containing $1 \%$ of acetone and precipitation from methanol $(300 \mathrm{~mL})$ by adding water $(150 \mathrm{~mL})$. Yield: $10.3 \mathrm{~g}$ $(908.7 \mathrm{~g} / \mathrm{mol}, 11.4 \mathrm{mmol}, 55 \%)$ of pale yellow solid.

${ }^{1} \mathrm{H}-\mathrm{NMR}\left(\mathrm{CDCl}_{3}, 400 \mathrm{MHz}\right): \delta=8.55-8.20$ (broad, $2 \mathrm{H}$ ), 8.20-7.65 (broad, 4H), 7.89 (s, 2H), 7.50-7.20 (broad, 2H) 7.05-6.45 (broad, $\left.6 \mathrm{H}\right), 4.23$ (t, $7 \mathrm{~Hz}$, $4 \mathrm{H}$ ), 4.30-4.10 (broad, 4H), 1.69 (sext, $7 \mathrm{~Hz}, 4 \mathrm{H}), 1.75-1.55$ (broad, $4 \mathrm{H}), 0.89$ (t, $7 \mathrm{~Hz}, 6 \mathrm{H}), 0.90-0.70$ (broad, $6 \mathrm{H}) \mathrm{ppm}$.

The strong signal broadening due to slow rotations, evident from the ${ }^{1} \mathrm{H}$-NMR spectrum, did not allow the recording of a meaningful ${ }^{13} \mathrm{C}$-NMR spectrum. FD-HRMS (m/z): $\mathrm{M}^{+}$Calcd for $\mathrm{C}_{48} \mathrm{H}_{44} \mathrm{Br}_{2} \mathrm{O}_{8}$ 906.1403; found 906.1409.

Mp.: $152-156^{\circ} \mathrm{C}$.

\section{Tetrapropyl dinaphtho[2,1-a;2,1-h]pyrene-5,6,14,15-tetracarboxylate 14a}

Bismaleate $12(1.0 \mathrm{~g}, 908.7 \mathrm{~g} / \mathrm{mol}, 1.1 \mathrm{mmol})$, palladium diacetate $(0.045 \mathrm{~g}, 224.5 \mathrm{~g} / \mathrm{mol}, 0.20 \mathrm{mmol})$, tricyclohexylphosphine $(0.13 \mathrm{~g}, 280.4 \mathrm{~g} / \mathrm{mol}$, $0.46 \mathrm{mmol})$ and potassium carbonate $(1.38 \mathrm{~g}, 138.2 \mathrm{~g} / \mathrm{mol}, 10.0 \mathrm{mmol})$ are stirred at $110^{\circ} \mathrm{C}$ in dry dimethylacetamide $(20 \mathrm{~mL})$ under argon for $19 \mathrm{~h}$. After cooling to room temperature, hot chloroform $(200 \mathrm{~mL})$ is added to the solidified mixture, insolubles are filtered off and discarded, and the chloroform is evaporated. Methanol $(100 \mathrm{~mL})$ is added, and the precipitate is filtered off and purified by column chromatography in DCM on silica and recrystallization from 1-butanol ( $300 \mathrm{~mL})$. Yield: $0.74 \mathrm{~g}(746.8 \mathrm{~g} / \mathrm{mol}, 0.99 \mathrm{mmol}, 90 \%)$ of orange solid.

${ }^{1} \mathrm{H}-\mathrm{NMR}\left(\mathrm{CDCl}_{3}, 400 \mathrm{MHz}\right): \delta=9.23(\mathrm{~s}, 2 \mathrm{H}), 8.91(\mathrm{~d}, 8 \mathrm{~Hz}, 2 \mathrm{H}), 8.51(\mathrm{~d}, 9 \mathrm{~Hz}, 2 \mathrm{H}), 8.26(\mathrm{~d}, 9 \mathrm{~Hz}, 2 \mathrm{H}), 8.04(\mathrm{~d}, 8 \mathrm{~Hz}, \mathrm{sH}), 7.78(\mathrm{t}, 8 \mathrm{~Hz}, 2 \mathrm{H}), 7.58(\mathrm{t}, 8 \mathrm{~Hz}$, $2 \mathrm{H}), 4.56(\mathrm{t}, 7 \mathrm{~Hz}, 4 \mathrm{H}), 4.44(\mathrm{t}, 7 \mathrm{~Hz}, 4 \mathrm{H}), 1.95(\mathrm{sext}, 7 \mathrm{~Hz}, 4 \mathrm{H}), 1.72(\mathrm{sext}, 7 \mathrm{~Hz}, 4 \mathrm{H}), 1.13(\mathrm{t}, 7 \mathrm{~Hz}, 6 \mathrm{H}), 0.87(\mathrm{t}, 7 \mathrm{~Hz}, 6 \mathrm{H}) \mathrm{ppm}$.

${ }^{13} \mathrm{C}-\mathrm{NMR}\left(\mathrm{CDCl}_{3}, 100 \mathrm{MHz}\right): \delta=171.0,168.9,131.9,130.6,129.5,128.7,128.5,127.7,127.4,127.3,126.6,126.2,126.1,123.7,123.4,121.5,119.9$, $68.2,68.1,22.3,21.8,10.8,10.7 \mathrm{ppm}$.

FD-HRMS (m/z): $\mathrm{M}^{+}$Calcd for $\mathrm{C}_{48} \mathrm{H}_{42} \mathrm{O}_{8} 746.2880$; found 746.2900 .

Mp.: $>320^{\circ} \mathrm{C}$.

\section{Tetrapropyl dinaphtho[2,1-a;1,2-i]pyrene-13,14,17,18-tetracarboxylate 15a}

Bismaleate $13(0.91 \mathrm{~g}, 908.7 \mathrm{~g} / \mathrm{mol}, 1.0 \mathrm{mmol})$, palladium diacetate $(0.045 \mathrm{~g}, 224.5 \mathrm{~g} / \mathrm{mol}, 0.20 \mathrm{mmol})$, tricyclohexylphosphine $(0.13 \mathrm{~g}, 280.4 \mathrm{~g} / \mathrm{mol}$, $0.46 \mathrm{mmol})$ and potassium carbonate $(1.38 \mathrm{~g}, 138.2 \mathrm{~g} / \mathrm{mol}, 10.0 \mathrm{mmol})$ are stirred at $110^{\circ} \mathrm{C}$ in dry dimethylacetamide $(20 \mathrm{~mL})$ under argon for $19 \mathrm{~h}$. After cooling to room temperature, hot chloroform $(200 \mathrm{~mL})$ is added to the solidified mixture, insolubles are filtered off and discarded, and the chloroform is evaporated. Methanol $(100 \mathrm{~mL})$ is added, and the precipitate is filtered off and purified by column chromatography on silica in DCM containing $1 \%$ of acetone and recrystallization from a mixture of 1 -butanol $(300 \mathrm{~mL})$ and dioxane $(50 \mathrm{~mL})$. Yield: $0.62 \mathrm{~g}(746.8 \mathrm{~g} / \mathrm{mol}, 0.83 \mathrm{mmol}, 83 \%)$ of yellow solid. ${ }^{1} \mathrm{H}-\mathrm{NMR}\left(\mathrm{CDCl}_{3}, 400 \mathrm{MHz}\right): \delta=9.06(\mathrm{~s}, 2 \mathrm{H}), 8.85(\mathrm{~d}, 8 \mathrm{~Hz}, 2 \mathrm{H}), 8.63(\mathrm{~s}, 2 \mathrm{H}), 8.12(\mathrm{~d}, 8 \mathrm{~Hz}, 2 \mathrm{H}), 7.96(\mathrm{~s}, 2 \mathrm{H}), 7.76(\mathrm{t}, 8 \mathrm{~Hz}, 2 \mathrm{H}), 7.66(\mathrm{t}, 8 \mathrm{~Hz}, 2 \mathrm{H}), 4.53(\mathrm{t}$, $7 \mathrm{~Hz}, 4 \mathrm{H}), 4.48(\mathrm{t}, 7 \mathrm{~Hz}, 4 \mathrm{H}), 1.92(\mathrm{sext}, 7 \mathrm{~Hz}, 4 \mathrm{H}), 1.83$ (sext, $7 \mathrm{~Hz}, 4 \mathrm{H}), 1.10(\mathrm{t}, 7 \mathrm{~Hz}, 6 \mathrm{H}), 0.98(\mathrm{t}, 7 \mathrm{~Hz}, 6 \mathrm{H}) \mathrm{ppm}$. 
${ }^{13} \mathrm{C}-\mathrm{NMR}\left(\mathrm{CDCl}_{3}, 100 \mathrm{MHz}\right): \delta=170.9,169.0,131.5,130.9,130.6,129.4,128.9,128.5,128.1,127.8,127.3,127.0,126.2,124.6,124.0,123.6,121.9$, 119.7, 68.4, 68.1, 22.3, 22.0, 10.9, $10.8 \mathrm{ppm}$.

FD-HRMS (m/z): $\mathrm{M}^{+}$Calcd for $\mathrm{C}_{48} \mathrm{H}_{42} \mathrm{O}_{8} 746.2880$; found 746.2882.

Mp.: 298-299ㄷ.

\section{Tetraoctyl dinaphtho[2,1-a;2,1-h]pyrene-5,6,14,15-tetracarboxylate 14c}

Tetrapropyl ester $14 \mathrm{a}(0.20 \mathrm{~g}, 746.8 \mathrm{~g} / \mathrm{mol}, 0.27 \mathrm{mmol})$ is refluxed under argon with potassium hydroxide $(0.30 \mathrm{~g}, 56.1 \mathrm{~g} / \mathrm{mol}, 5.4 \mathrm{mmol})$ in ethylene $\mathrm{glycol}$ $(25 \mathrm{~mL})$ for $16 \mathrm{~h}$. The heterogeneous mixture is cooled to room temperature and poured into $2 \mathrm{M}$ aqueous hydrochloric acid (200mL) with stirring. The formed precipitate is filtered off and washed with water on the glass frit. To remove remaining water, acetone (50mL) is added four times and evaporated. Then a solution of DBU $(0.32 \mathrm{~g}, 152.2 \mathrm{~g} / \mathrm{mol}, 2.1 \mathrm{mmol})$, octanol $(0.70 \mathrm{~g}, 130.2 \mathrm{~g} / \mathrm{mol}, 5.4 \mathrm{mmol})$ and $1-\mathrm{bromooctane}(1.04 \mathrm{~g}, 193.1 \mathrm{~g} / \mathrm{mol}$, $5.4 \mathrm{mmol})$ in dry THF $(50 \mathrm{~mL})$ is added and the mixture is stirred at reflux under exclusion of moisture for $16 \mathrm{~h}$. After cooling to room temperature, the mixture is poured into $2 \mathrm{M}$ aqueous hydrochloric acid $(150 \mathrm{~mL})$ and the product is extracted with chloroform $(3 \times 100 \mathrm{~mL})$. The solution is dried with sodium sulfate, the solvent is evaporated and the product is precipitated with methanol. The precipitate is filtered off and purified by column chromatography in DCM on silica and recrystallization from butanol. Yield: $0.14 \mathrm{~g}(1027.4 \mathrm{~g} / \mathrm{mol}, 0.14 \mathrm{mmol}, 50 \%)$ of orange solid.

${ }^{1} \mathrm{H}-\mathrm{NMR}\left(\mathrm{CDCl}_{3}, 400 \mathrm{MHz}\right): \delta=9.14(\mathrm{~s}, 2 \mathrm{H}), 8.83(\mathrm{~d}, 8 \mathrm{~Hz}, 2 \mathrm{H}), 8.44(\mathrm{~d}, 9 \mathrm{~Hz}, 2 \mathrm{H}), 8.19(\mathrm{~d}, 9 \mathrm{~Hz}, 2 \mathrm{H}), 7.96(\mathrm{~d}, 8 \mathrm{~Hz}, \mathrm{sH}), 7.73(\mathrm{t}, 8 \mathrm{~Hz}, 2 \mathrm{H}), 7.48(\mathrm{t}, 8 \mathrm{~Hz}$, $2 \mathrm{H}), 4.54(\mathrm{t}, 7 \mathrm{~Hz}, 4 \mathrm{H}), 4.41(\mathrm{t}, 7 \mathrm{~Hz}, 4 \mathrm{H}), 1.86$ (quint, $7 \mathrm{~Hz}, 4 \mathrm{H}), 1.60$ (quint, $7 \mathrm{~Hz}, 4 \mathrm{H}), 1.49$ (quint, $7 \mathrm{~Hz}, 4 \mathrm{H}), 1.39(q u i n t, 7 \mathrm{~Hz}, 4 \mathrm{H}), 1.37-1.21(\mathrm{~m}, 12 \mathrm{H})$, $1.19-1.06(\mathrm{~m}, 8 \mathrm{H}), 1.06-0.91(\mathrm{~m}, 12 \mathrm{H}), 0.87(\mathrm{t}, 7 \mathrm{~Hz}, 6 \mathrm{H}), 0.66(\mathrm{t}, 7 \mathrm{~Hz}, 6 \mathrm{H}) \mathrm{ppm}$.

${ }^{13} \mathrm{C}-\mathrm{NMR}\left(\mathrm{CDCl}_{3}, 100 \mathrm{MHz}\right): \delta=171.0,168.8,131.8,130.6,129.5,128.7,128.5,127.7,127.4,127.3,126.6,126.2,123.7,123.4,121.5,119.8,66.74$, 66.66, 32.0, 31.8, 29.53, 29.45, 29.36, 29.25, 28.9, 28.4, 26.3, 26.2, 22.9, 22.6, 14.3, $14.1 \mathrm{ppm}$.

FD-HRMS (m/z): $\mathrm{M}^{+}$Calcd for $\mathrm{C}_{68} \mathrm{H}_{82} \mathrm{O}_{8} 1026.6010$; found 1026.6013

Mp.: 203-204은

The ethyl and 3-methylpentyl esters 14b (Mp.:>320ㄷ) and 14d (Mp.: 258-259 $\mathrm{C})$ are obtained similarly in $60 \%$ and $40 \%$ yield.

\section{Tetraoctyl dinaphtho[2,1-a;1,2-i]pyrene-13,14,17,18-tetracarboxylate 15c}

Tetraoctyl ester $15 \mathrm{c}$ is obtained from tetrapropyl ester $15 \mathrm{a}(0.20 \mathrm{~g}, 746.8 \mathrm{~g} / \mathrm{mol}, 0.27 \mathrm{mmol})$ following the preceding procedure in $60 \%$ yield $(0.16 \mathrm{~g}$, $1027.4 \mathrm{~g} / \mathrm{mol}, 0.15 \mathrm{mmol}$ ) as a yellow solid.

${ }^{1} \mathrm{H}-\mathrm{NMR}\left(\mathrm{CDCl}_{3}, 400 \mathrm{MHz}\right): \delta=8.69(\mathrm{~s}, 2 \mathrm{H}), 8.59(\mathrm{~d}, 8 \mathrm{~Hz}, 2 \mathrm{H}), 8.58(\mathrm{~s}, 2 \mathrm{H}), 8.02(\mathrm{~d}, 8 \mathrm{~Hz}, 2 \mathrm{H}), 7.67(\mathrm{~s}, 2 \mathrm{H}), 7.59(\mathrm{t}, 8 \mathrm{~Hz}, 2 \mathrm{H}), 7.53(\mathrm{t}, 8 \mathrm{~Hz}, 2 \mathrm{H}), 4.58(\mathrm{t}$, $7 \mathrm{~Hz}, 4 \mathrm{H}$ ), $4.55(\mathrm{t}, 7 \mathrm{~Hz}, 4 \mathrm{H}), 1.92$ (quint, $7 \mathrm{~Hz}, 4 \mathrm{H}), 1.82$ (quint, $7 \mathrm{~Hz}, 4 \mathrm{H}), 1.53$ (quint, $7 \mathrm{~Hz}, 4 \mathrm{H}), 1.47-1.23(\mathrm{~m}, 24 \mathrm{H}), 1.21-1.08(\mathrm{~m}, 12 \mathrm{H}), 0.88(\mathrm{t}, 7 \mathrm{~Hz}, 6 \mathrm{H}$ ), $0.76(\mathrm{t}, 7 \mathrm{~Hz}, 6 \mathrm{H}) \mathrm{ppm}$.

${ }^{13} \mathrm{C}-\mathrm{NMR}\left(\mathrm{CDCl}_{3}, 100 \mathrm{MHz}\right): \delta=170.9,169.0,131.4,130.8,130.5,129.2,128.7,128.4,128.0,127.6,127.1,126.9,126.1,124.6,123.8,123.5,121.7$, 119.6, 67.0, 66.7, 32.1, 32.0, 29.56, 29.54, 29.48, 29.46, 29.0, 28.7, 26.4, 26.3, 22.9, 22.8, 14.3, 14.2 ppm.

FD-HRMS (m/z): $\mathrm{M}^{+}$Calcd for $\mathrm{C}_{68} \mathrm{H}_{82} \mathrm{O}_{8}$ 1026.6010; found 1026.6001.

Mp.: $164-165^{\circ} \mathrm{C}$.

The ethyl and 3-methylpentyl esters 15b (Mp.: $\left.>320^{\circ} \mathrm{C}\right)$ and $15 \mathrm{~d}\left(\mathrm{Mp} .: 216-217^{\circ} \mathrm{C}\right)$ are obtained similarly in $60 \%$ and $55 \%$ yield.

\section{N,N'-bis(1-hexyldecyl) dinaphtho[2,1-a;2,1-h]pyrene-5,6:14,15-tetracarboxdiimide 4d}

Tetrapropyl ester $14 \mathrm{a}(0.15 \mathrm{~g}, 746.8 .0 \mathrm{~g} / \mathrm{mol}, 0.20 \mathrm{mmol}), 7$-aminohexadecane $(0.14 \mathrm{~g}, 227.4 \mathrm{~g} / \mathrm{mol}, 0.62 \mathrm{mmol})$ and imidazole $(6 \mathrm{~g})$ are stirred at reflux under argon in o-dichlorobenzene $(10 \mathrm{~g})$ for $16 \mathrm{~h}$. Then the mixture is poured into hot chloroform (200mL) and the solution is washed with $2 \mathrm{M}$ aqueous hydrochloric acid $(200 \mathrm{~mL})$. The organic phase is dried with sodium sulfate, the solvent is evaporated and the product is purified by column chromatography on silica in a 3:2 mixture of petrol ether and chloroform followed by recrystallization from butanol. Yield: $0.10 \mathrm{~g}(989.4 \mathrm{~g} / \mathrm{mol}, 0.10 \mathrm{mmol}$, $50 \%)$ of purple-red solid.

${ }^{1} \mathrm{H}-\mathrm{NMR}\left(\mathrm{CDCl}_{3}, 400 \mathrm{MHz}\right): \delta=9.60(\mathrm{~d}, 9 \mathrm{~Hz}, 2 \mathrm{H}), 9.39(\mathrm{~s}, 2 \mathrm{H}), 9.34(\mathrm{~d}, 8 \mathrm{~Hz}, 2 \mathrm{H}), 8.99(\mathrm{~d}, 8 \mathrm{~Hz}, 2 \mathrm{H}), 8.41(\mathrm{~d}, 9 \mathrm{~Hz}, 2 \mathrm{H}), 7.91(\mathrm{t}, 8 \mathrm{~Hz}, 2 \mathrm{H}), 7.81(\mathrm{t}, 8 \mathrm{~Hz}$, $2 \mathrm{H}), 4.41(\mathrm{tt}, 10 \mathrm{~Hz}, 5 \mathrm{~Hz}, 2 \mathrm{H}), 2.32-2.20(\mathrm{~m}, 4 \mathrm{H}), 1.91-1.79(\mathrm{~m}, 4 \mathrm{H}), 1.47-1.32(\mathrm{~m}, 16 \mathrm{H}), 1.32-1.13(\mathrm{~m}, 28 \mathrm{H}), 0.85(\mathrm{t}, 7 \mathrm{~Hz}, 6 \mathrm{H} 0,0.80(\mathrm{t}, 7 \mathrm{~Hz}, 6 \mathrm{H}) \mathrm{ppm}$. ${ }^{13} \mathrm{C}-\mathrm{NMR}\left(\mathrm{CDCl}_{3}, 100 \mathrm{MHz}\right): \delta=170.2,133.4,131.9,131.3,130.6,129.7,128.7,127.9,126.9,126.7,125.3,123.7,123.6,121.0,120.2,52.9,33.0$, 32.1, 29.8, 29.7, 29.5, 29.4, 27.2, 22.9, $14.3 \mathrm{ppm}$.

FD-HRMS (m/z): $\mathrm{M}^{+}$Calcd for $\mathrm{C}_{68} \mathrm{H}_{80} \mathrm{~N}_{2} \mathrm{O}_{4}$ 988.6118; found 988.6125

The 1-pentylhexyl, 1-undecyldodecyl, 1-propyloctyl and 1-butyldodecyl imides $4 \mathbf{a}, \mathbf{4 b}, \mathbf{4 c}$ and $\mathbf{4 e}$ are obtained similarly in $75 \%$, $60 \%$, $75 \%$ and $50 \%$ yield.

\section{N,N'-bis(1-hexyldecyl) dinaphtho[2,1-a;1,2-i]pyrene-13,14:17,18-tetracarboxdiimide 16d}

1 -hexyldecyl imide $16 \mathrm{~d}$ is obtained from tetrapropyl ester $15 \mathrm{a}(0.15 \mathrm{~g}, 746.8 \mathrm{~g} / \mathrm{mol}, 0.20 \mathrm{mmol})$ following the preceding procedure in $70 \%$ yield $(0.14 \mathrm{~g}$, $989.4 \mathrm{~g} / \mathrm{mol}, 0.14 \mathrm{mmol})$ as a red-brown solid.

${ }^{1} \mathrm{H}-\mathrm{NMR}\left(\mathrm{CDCl}_{3}, 400 \mathrm{MHz}\right): \delta=10.04(\mathrm{~s}, 2 \mathrm{H}), 9.37(\mathrm{~d}, 8 \mathrm{~Hz}, 2 \mathrm{H}), 9.14(\mathrm{~s}, 2 \mathrm{H}), 8.88(\mathrm{~d}, 8 \mathrm{~Hz}, 2 \mathrm{H}), 8.08(\mathrm{~s}, 2 \mathrm{H}), 7.84(\mathrm{t}, 8 \mathrm{~Hz}, 2 \mathrm{H}), 7.77(\mathrm{t}, 8 \mathrm{~Hz}, 2 \mathrm{H}), 4.47$ $(\mathrm{tt}, 10 \mathrm{~Hz}, 5 \mathrm{~Hz}, 2 \mathrm{H}), 2.36-2.23(\mathrm{~m}, 4 \mathrm{H}), 1.94-1.83(\mathrm{~m}, 4 \mathrm{H}), 1.50-1.33(\mathrm{~m}, 16 \mathrm{H}), 1.33-1.13(\mathrm{~m}, 28 \mathrm{H}), 0.85(\mathrm{t}, 7 \mathrm{~Hz}, 6 \mathrm{H} 0,0.79(\mathrm{t}, 7 \mathrm{~Hz}, 6 \mathrm{H}) \mathrm{ppm}$.

${ }^{13} \mathrm{C}-\mathrm{NMR}\left(\mathrm{CDCl}_{3}, 100 \mathrm{MHz}\right): \delta=170.3,170.1,133.1,132.2,131.6,129.6,129.3,128.6,128.4,128.2,127.5,126.3,125.5,123.5,123.2,121.7,120.0$, 53.1, 33.1, 32.1, 29.9, 29.84, 29.80, 29.52, 29.45, 27.4, 27.3, 22.90, 22.85, 14.32, $14.27 \mathrm{ppm}$.

FD-HRMS (m/z): $\mathrm{M}^{+}$Calcd for $\mathrm{C}_{68} \mathrm{H}_{80} \mathrm{~N}_{2} \mathrm{O}_{4}$ 988.6118; found 988.6115 .

The 1-pentylhexyl, 1-undecyldodecyl, 1-propyloctyl and 1-butyldodecyl imides 16a, 16b, 16c and 16e are obtained similarly in $90 \%$, 40\%, $90 \%$ and $75 \%$ yield.

\section{Acknowledgements}

We are grateful to Ivan $\mathrm{H}$. Bechtold for his support and to Frédéric Nallet for helpful discussions. This research was financed partially by Coordenação de Aperfeiçoamento de Pessoal de Nível Superior - Comité Français d'Evaluation de la Coopération Universitaire et Scientifique avec le Brésil (CAPES-COFECUB, project Ph-C 80314) and Agence Nationale de la Recherche (ANR, project 13-JS07-0009-01) grants. Electronic Supporting information: Powder X-ray diffraction data, Cyclovoltammograms, ${ }^{1} \mathrm{H}$ - and ${ }^{13} \mathrm{C}-\mathrm{NMR}$ spectra. 
Keywords: liquid crystals $•$ fused-ring systems $\bullet$ donor-acceptor systems $\bullet$ stacking interactions $\bullet$ phase transitions

[1] S. Laschat, A. Baro, N. Steinke, F. Giesselmann, C. Hägele, G. Scalia, R. Judele, E. Kapatsina, S. Sauer, A. Schreivogel, M. Tosoni, Angew. Chem. Int Ed. 2007, 46, 4832.

[2] R. J. Bushby. O. R. Lozman, Curr. Opinion Colloid Interf. Sci. 2002, 7, 343.

[3] a) J. Kelber, M.-F. Achard, B. Garreau-de Bonneval, H. Bock, Chem. Eur. J. 2011, 17, 8145; b) J. Kelber, M.-F. Achard, F. Durola,, H. Bock, Angew. Chem. Int. Ed. 2012, 51, 5200 .

[4] a) A. Wicklein, A. Lang, M. Muth, M. Thelakkat, J. Am. Chem. Soc. 2009, 131, 14442; b) F. Nolde, W. Pisula, S. Müller, C. Kohl, K. Müllen, Chem. Mater. 2006, 18, 3715.

[5] M. Ferreira, E. Girotto, A. Bentaleb, E. A. Hillard, H. Gallardo, F. Durola, H. Bock, Chem. Eur. J., in press (DOI: 10.1002/chem.201406172).

[6] R. G. Harvey, J. Pataki, H. Lee, Org. Prep. Proc. Int. 1984, 16, 144.

[7] a) H. Bock, P. Carré, E. A. Hillard, F. Durola, Eur. J. Org. Chem. 2015, 1028; b) H. Bock, S. Huet, P. Dechambenoit, E. A. Hillard, F. Durola, Eur. J. Org. Chem. 2015, 1033.

[8] A. M. Levelut, J. Chimie Physique 1983, 80, 149

[9] Densities obtained by SAXS: 16b: $1.02\left(110^{\circ} \mathrm{C}\right), 1.06\left(40^{\circ} \mathrm{C}\right) ; 16 \mathrm{~d}: 1.01\left(235^{\circ} \mathrm{C}\right), 1.03\left(210^{\circ} \mathrm{C}\right), 1.06\left(150^{\circ} \mathrm{C}\right) ; 4 \mathrm{~d}: 1.04\left(190^{\circ} \mathrm{C}\right) \mathrm{g} / \mathrm{cm}^{3}(\mathrm{see} \mathrm{ESI})^{\circ}$

[10] J. Tang, R. Huang, H. Gao, X. Cheng, M. Prehm, C. Tschierske, RSC Advances 2012, 2, 2842.

[11] a) E.-W. Lee, M. Hattori, F. Uehara, M. Tokita, S. Kawauchi, J. Watanabe, S. Kang, J. Mater. Chem. C, in press (DOI: 10.1039/c4tc02723j); b) E. Gorecka, N. Vaupotič, D. Pociecha, Chem. Mater. 2007, 19, 3027.

[12] a) B. Bilgin-Eran, C. Tschierske, S. Diele, U. Baumeister, J. Mater. Chem. 2006, 16, 1145; b) T. Hegmann, J. Kain, S. Diele, B. Schubert, H. Bögel, C. Tschierske, J. Mater. Chem. 2003, 13, 991.

[13] E. M. García-Frutos, G. Bottari, Purificación Vázquez, Joaquín Barberá, T. Torres, Chem. Commun. $2006,3107$.

[14] C. Destrade, P. Foucher, H. Gasparoux, Nguyen H. T., A. M. Levelut, J. Malthête, Mol. Cryst. Liq. Cryst. $1984,106,121$.

[15] a) S. J. Cross, J. W. Goodby, A. W. Hall, M. Hird, S. M. Kelly, K. J. Toyne, C. Wu, Liq. Cryst. 1998, 25, 1; b) B. Glüsen, W. Heitz, A. Kettner, J. H. Wendorff, Liq. Cryst. 1996, 20, 627.

[16] J. Barberà, O. A. Rakitin, M. B. Ros, T. Torroba, Angew. Chem. Int. Ed. 1998, 37, 296.

[17] P. Sarkar, F. Durola, H. Bock, Chem. Commun. 2013, 49, 7552. 